\title{
The etiological role of the parainfluenza-3 virus in the respiratory pathology of young cattle
}

\author{
Achouak Gueriche ${ }^{1}$, Albert K. Galiullin ${ }^{1 *}$, Vali G. Gumerov ${ }^{2}$, Ilsiyar G. Karimullina ${ }^{2}$, and Aigul Y. Shaeva ${ }^{1}$ \\ ${ }^{1}$ Kazan State Academy of Veterinary Medicine named after N.E. Bauman, Kazan 420029, Russia \\ ${ }^{2}$ Federal centre for toxicological, radiation and biological safety, Scientific town-2, Kazan city 420075, Russia
}

\begin{abstract}
Parainfluenza virus-3 is the most common etiological agent in mixed respiratory diseases of calves with high concentrations of animals. The more severe course of the disease is observed with complications from bacterial or other viral infections. This article presents the results of clinical and epizootic, serological, virological and molecular genetic studies. A cytopathogenic agent was isolated from a pathological material taken from patients with respiratory diseases of calves in a BEK cell culture. Based on the results of serological and molecular biological studies, this isolate ("LD-9") was identified as the parainfluenza-3 virus in cattle.
\end{abstract}

\section{Introduction}

The Bovine respiratory diseases complex (BRDC) is a major health problem for cattle worldwide $[1,2]$. The multiple factors that cause BRDC include stress, infectious agents, immunity, and housing conditions. The infectious agents associated with BRDC include viruses, bacteria, and mycoplasmas [3-5]. While most acute infections with uncomplicated infectious agents are sub-clinical, they can cause respiratory disease. [6]. The primary viral infectious pathogens that cause BRDC are bovine parainfluenza virus 3 (BPIV3), bovine respiratory syncytial virus (BRSV), bovine viral diarrhea virus (BVDV), bovine alphaherpesvirus 1 (BHV-1), bovine coronavirus (BCV), and so forth $[7,8]$. According to the prevalence, mortality, forced slaughter, underweight, the respiratory diseases prevail in calves over all other diseases.

Bovine parainfluenza virus type 3 (BPIV3) was one of the most important viruses associated with BRDC in cattle [5, 9]. It was first isolated in 1959 and first identified in cases of BRDC [5].

BPIV-3 is an enveloped, nonsegmented, negativesense and single-stranded RNA virus belonging to the Respirovirus genus in the family Paramyxoviridae [10].

Bovine parainfluenza type 3 (infectious bronchitis, bronchopneumonia, acute upper respiratory tract catarrhage, transport fever or Parainfluenza-3) is an acute infectious disease of cattle (mostly young cattle up to 6 months of age) characterized by catarrhally-purulent respiratory disease, fever, general deppression, dry, painful cough attacks, and catarrhal conjunctivitis. The disease is registered in all countries where cattle breeding is developed. Unfavorable factors contribute to the development of the disease are overcrowding, poor nutrition and high contamination of livestock buildings [9, 11-14].
Parainfluenza-3 of cattle is clinically identical to many other respiratory diseases (infectious rhinotracheitis (IRT), respiratory syncytial (RS), bovine viral diarrhea (BVD), adenovirus infection, etc.). Diagnostic complexity is increased due to the constant mixed course of the disease (complication of salmonellosis, staphylococcosis, pasteurellosis, coccal infection, etc.). Predictive diagnosis is made on the basis of the assessment of the epizootic situation (previous years cases of the disease, importation of cattle from indemic regions) and external signs, the final diagnosis is based on the results of virological, serological and molecular genetic studies [15-18].

Laboratory diagnosis of parainfluenza- 3 of cattle is based on the detection of viral antigens in detachable cells of the nasal mucosa of patients or in epithelial cells of the trachea and bronchi of dead animals, the isolation and identification of the virus, as well as the detection of increases in specific antibodies in paired serum samples of animal-reconvalescents.

When making a diagnosis of PI-3, it is necessary to exclude other viral diseases, especially adenoviral bronchopneumonia, infection rhinotracheitis, respiratory syncytial infection and viral diarrhea $[17,19]$.

\section{Materials and methods}

In the course of the epizootic survey of a dysfunctional farm where an outbreak of respiratory disease in calves was registered, the analysis was first carried out of the quantitative and sex-age composition of animals, their placement and the nature of livestock breeding/ Additionally, the data on diseases previously registered in the farm was initially collected. Subsequently, the seasonality of the infection, the nature of the disease, the sources and routes of transmission of pathogens, the

* Corresponding author: albert-954@ mail.ru 
possibility of different age group being involved in the infectious process were taken into account, as well as general breeding conditions, like feeding animals and veterinary and sanitary conditions of livestock building.

Clinical examination of sick calves was carried out by standard methods (measurement of body temperature, pulse rate and respiratory rate). During clinical examination of animals, visible mucous membranes of the nasal and oral cavities, as well as the conjunctiva, were carefully examined, paying attention to their color, the presence of secretions from these cavities, as well as possible defects (erosion, ulcers) of the mucous membranes.

Pathological anatomical autopsy of the calves who were forcedly killed and dead by respiratory diseases was carried out according to the generally accepted method. During the inspection, special attention was paid to the presence of characteristic changes in the respiratory tract.

Retrospective serological diagnostics was based on the detection of 2-4-fold increase of specific antibodies to PI-3 virus in the hemagglutination inhibition test (HGIT) in paired blood serum samples taken in the initial stage of the disease and 3 weeks after the reconstruction. For the hemagglutination inhibition reaction, we used the set of diagnostic instruments by FSI "Kursk Biofactory- BIOK company".

Virological studies were performed using a primary culture of a bovine embryo kidney cell (BEK) and transplantable bovine embryonic kidney (MDBK Madin-Darby bovine kidney), and Syrian hamster kidney clone 13 (BHK-21/13 - Baby Hamster Kidney) cell line cultures. For the cultivation of cell cultures, cattle serum was used, manufactured at the Federal center for toxicological, radiation and biological safety.

Molecular biological studies of cell cultures for possible contamination with herpesvirus type 1 and diarrhea virus were carried out using the RINOCOR Test System to identify the causative agent of cattle rhinotracheitis and the VD Test System for detecting cattle viral diarrhea by PCR with hybridizationfluorescence detection in real time (FBIS Central Research Institute of Epidemiology, Moscow).

In order to isolate the suspected pathogens of respiratory pathology of young cattle from sick calves and fallen animal, nasal discharge, pieces of organs and tissues (mucous membrane of nasal partitions and tracheas, lungs, lymph nodes, spleen, liver, kidneys) were taken. These materials were used to prepare $10 \%$ suspensions using Henks solution containing a mixture of penicillin antibiotics with streptomycin. Then suspensions of the materials infected the cell culture of BEK. For this purpose, a monolayer of cell culture was washed with Henks solution three times to remove serum antibodies and inhibitors present in the growth medium. After that, $0.2 \mathrm{~cm}^{3}$ of suspensions of the studied materials were added to the bottles and left on contact at $37 \mathrm{C}$ for 1 hour. After incubation, the suspension of pathological materials was removed and the monolayer was washed with Henks solution 2-3 times. After that, the supportive medium (the lactic albumin hydrolysate) was added to all bottles with cell culture and put into the thermostat.
Bottles with infected cell culture were examined daily under low light microscope magnification for cytopathic effect (CPE). In those cases where 6-7 days after the initial infection no CPE was detected on the monolayer, 2-3 "blind" passages were performed additionally.

Serological identification of viral isolate was carried out in neutralization reaction (NR) with a constant dose of the virus $\left(100\right.$ TCE $\left.50 / \mathrm{cm}^{3}\right)$ and diffusion precipitation reaction (DPR) by conventional methods. For experiments, we used monospecific hyperimmune serum obtained for reference strains of IRT, PI-3, BVD, $\mathrm{RS}$ viruses and cattle adenoviruses of the 1st and 2nd subgroups.

In order to confirm the affiliation of the isolated isolate to the RNA-containing parainfluenza-3 virus, a polymerase chain reaction was carried out by reverse transcription method with fluorescence detection in real time using the PCR-PARAGRIP-3-KRS-FACTOR kit (VET-FACTOR), Troitsk). RNA extraction was carried out by the sorption method using the commercial DNARNA-S-FACTOR kit of the same manufacturer. Amplification was carried out on a DT-Light device (DNA technology, Russia) using the temperature regime specified in the manufacturer's instructions (table 1).

Table 1. Temperature-time amplification mode.

\begin{tabular}{|c|c|c|}
\hline № & Temperature-time mode & Number of cycles \\
\hline 1 & $55^{\circ} \mathrm{C}-15 \mathrm{~min}$ & 1 \\
\hline 2 & $95^{\circ} \mathrm{C}-5 \mathrm{~min}$ & 1 \\
\hline \multirow{3}{*}{3} & $95^{\circ} \mathrm{C}-20 \mathrm{~s}$ & \multirow{2}{*}{45} \\
\cline { 2 - 2 } & $95^{\circ} \mathrm{C}-30 \mathrm{~s}$ & \\
\cline { 2 - 3 } & $95^{\circ} \mathrm{C}-20 \mathrm{~s}$ & \\
\hline
\end{tabular}

\section{Research results}

In wintertime, one of the dairy complexes of the Republic of Tatarstan registered an outbreak of respiratory disease among calves of 1-3 months of age. Clinical signs of the disease were characterized by an increase in body temperature up to $41-42{ }^{\circ} \mathrm{C}$, deppression, dyspnea, serous-mucosal discharge from the nose, eyes, diarrhea and refusal of food was observed in some animals (Fig. 1).

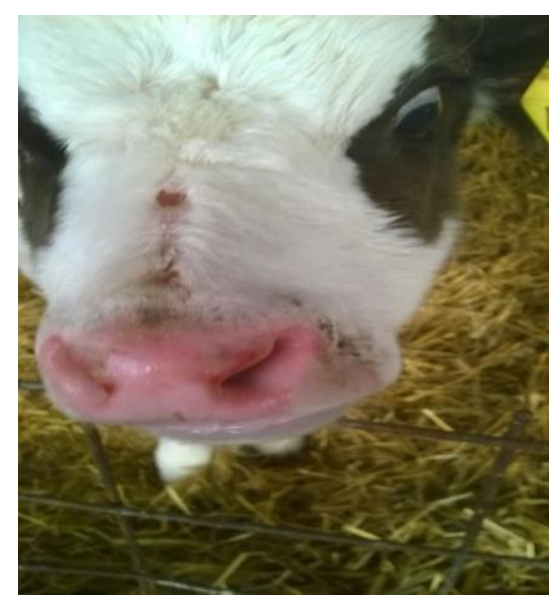

Fig. 1. Sick calf with signs of respiratory disease 
The calf was found to have hyperemia of the lung with areas of red seal (Fig. 2), surrounded by a zone of emphysema. The mucous membrane of the trachea, bronchiol and bronchiol was hyperemiatized and covered with muco-purulent exudate (Fig. 3).

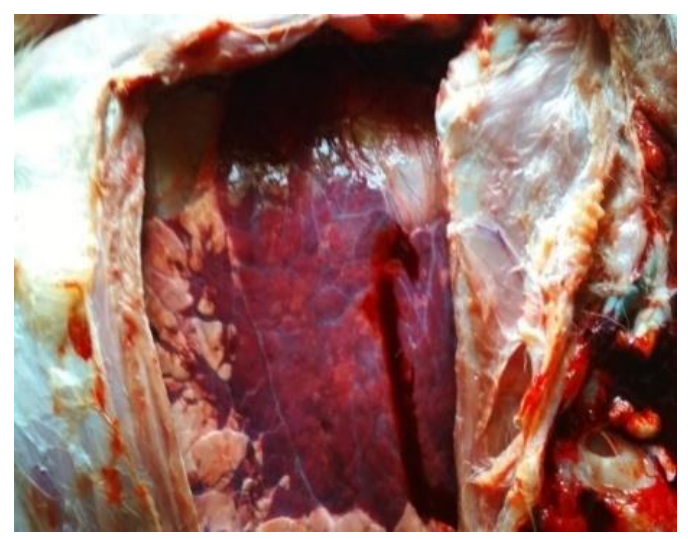

Fig. 2. Lung lesions with red sealing areas.

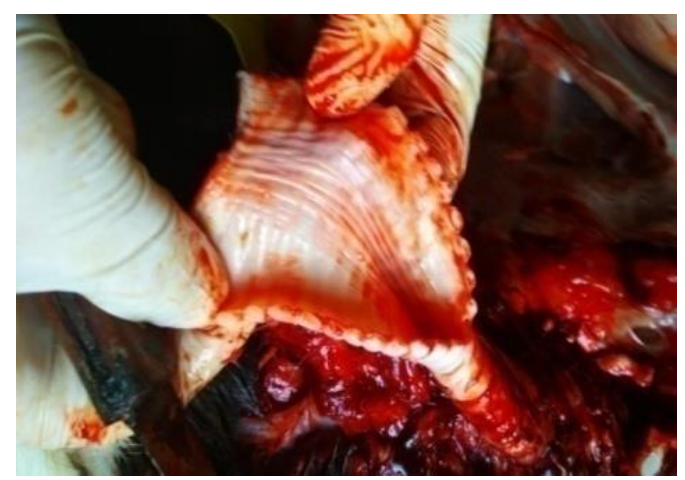

Fig. 3. Hyperemia of the tracheal mucosa.

In order to make a diagnosis of respiratory disease, retrospective studies of 12 serum samples from 1 to 3 month-old patients and recovered calves were performed in the HGIT. The results of the studies are presented in Table 2.

Table 2. Results of retrospective serological studies.

\begin{tabular}{|c|c|c|c|c|}
\hline \multirow[t]{2}{*}{ № } & \multirow[t]{2}{*}{$\begin{array}{l}\text { No. of } \\
\text { animals }\end{array}$} & \multirow[t]{2}{*}{$\begin{array}{l}\text { Age of } \\
\text { calves }\end{array}$} & \multicolumn{2}{|c|}{$\begin{array}{c}\text { Titers of antihemagglutinins to } \\
\text { PI-3 virus in calf serum in } \\
\text { HGIT }\end{array}$} \\
\hline & & & patients & recovered \\
\hline 1 & 347 & \multirow{4}{*}{1 month } & $1: 20$ & $1: 80$ \\
\hline 2 & 335 & & $1: 10$ & $1: 160$ \\
\hline 3 & 356 & & $1: 20$ & $1: 80$ \\
\hline 4 & 361 & & $1: 20$ & $1: 80$ \\
\hline 5 & 241 & \multirow{4}{*}{$\begin{array}{c}2 \\
\text { months }\end{array}$} & $1: 5$ & $1: 80$ \\
\hline 6 & 229 & & $1: 5$ & $1: 80$ \\
\hline 7 & 244 & & 0 & $1: 40$ \\
\hline 8 & 235 & & $1: 10$ & $1: 160$ \\
\hline 9 & 118 & \multirow{4}{*}{$\begin{array}{c}3 \\
\text { months }\end{array}$} & 0 & $1: 40$ \\
\hline 10 & 126 & & $1: 5$ & $1: 80$ \\
\hline 11 & 115 & & $1: 5$ & $1: 80$ \\
\hline 12 & 110 & & 0 & $1: 80$ \\
\hline
\end{tabular}

Analysis of the serological results showed that at the initial stage of the disease the calves have no colostrum antibodies to the PI-3 virus or they are detected in low titers $(1: 5-1: 20)$. In turn, it should be noted that in cases of sick calves, their level increases 2-4 times (1:40$1: 160)$. Identification of the growth of specific antibodies in animals-convalescents indicates that one of the etiological agents of respiratory pathology of calves in the studied economy is the parainfluenza virus- 3 cattle.

The next step of our research was the determination (by PCR) of the possible contamination by IRT, PI-3, $\mathrm{BVD}$ viruses of the 3 cell culture lines used in the work (MDBK, BEK and BHK-21/13). The research results presented in table 3 showed that the cultures of MDBK and BHK-21/13 were contaminated with the virus of viral diarrhea - a disease of the mucous membranes of cattle. In this regard, in further experiments, only BEK cell culture was used.

Table 3. The results of molecular genetic research.

\begin{tabular}{|c|c|c|c|c|c|}
\hline \multirow[b]{2}{*}{ № } & \multirow[b]{2}{*}{$\begin{array}{c}\text { Cell culture } \\
\text { names }\end{array}$} & \multicolumn{2}{|c|}{ BHV-1 } & \multicolumn{2}{|c|}{ BVDV } \\
\hline & & $\begin{array}{c}\text { reac- } \\
\text { tion }\end{array}$ & $\begin{array}{c}\text { concen- } \\
\text { tration/ } \\
\mathrm{ml}\end{array}$ & $\begin{array}{c}\text { reac- } \\
\text { tion }\end{array}$ & $\begin{array}{c}\text { concen- } \\
\text { tration/ } \\
\mathrm{ml}\end{array}$ \\
\hline 1 & MBDK & - & 0 & + & $1 * 10^{6}$ \\
\hline 2 & BEK & - & 0 & - & 0 \\
\hline 3 & BHK21/13 & - & 0 & + & $2 * 10^{4}$ \\
\hline
\end{tabular}

Note: + positive result; - negative result

In order to isolate etiological agents, suspensions of clinical and pathological materials taken from sick calves and fallen animal, they infected the bovine kidney cell culture. It should be noted that the cytopathogenic agent ("LD-9") was isolated on the second passageway, which caused degenerative changes in the monolayer for 98-124 hours. The CPE of the isolate "LD-9"on the monolayer of the cell culture was characterized by the formation of syncytium and vacuoles (Fig. 4). In the following passages, the cytopathic effect was reduced to 72 hours.

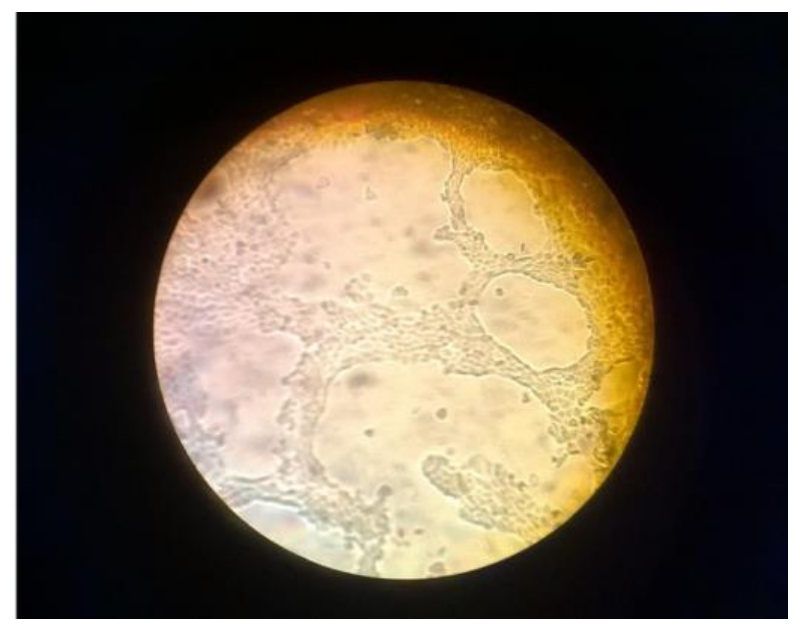

Fig. 4. LD-9 isolate CPE on bovine kidney cell culture.

In order to identify the viral isolate, neutralization reactions on cell culture and diffusion precipitation on Difco agar were put forward. The results of the studies are presented in Table 2. 
Table 4.Serological identification of the viral isolate «LD-9».

\begin{tabular}{|c|c|c|c|}
\hline \multirow{2}{*}{$\begin{array}{c}\text { Reference } \\
\text { antiserum to } \\
\text { viruses of: }\end{array}$} & Stamp & \multicolumn{2}{|c|}{ Titers of antibodies $\left(\log _{2}\right)$} \\
\cline { 3 - 4 } & $\begin{array}{c}\text { Neutralization } \\
\text { reaction }\end{array}$ & $\begin{array}{c}\text { Diffusion } \\
\text { precipitation } \\
\text { reaction }\end{array}$ \\
\hline $\begin{array}{c}\text { Infectious } \\
\text { rhinotracheitis }\end{array}$ & $\begin{array}{c}\text { «T-A (RNIEV)- } \\
\text { B2» }\end{array}$ & 0 & 0 \\
\hline Parainfluenza-3 & «TK-45/86» & 5,0 & 2,0 \\
\hline $\begin{array}{c}\text { Respiratory- } \\
\text { syncytial }\end{array}$ & «Rondal» & 0 & 0 \\
\hline Viral diarrhea & «VK-1» & 0 & 0 \\
\hline Adenovirus-1 & «Bovina-10» & 0 & 0 \\
\hline Adenovirus-2 & «WBR-1» & 0 & 0 \\
\hline
\end{tabular}

Analysis of the research results showed that «LD-9»» isolate reacts with a specific serum to the PI-3 virus in a titer of $1: 32$ in the NR and a titer of $1: 4$ in the DPR. Seropositivity to other viral agents has not been established. The results of virological studies indicate that the cytopathogenic agent isolated on the cell culture of BEK is a parainfluenza-3 virus in cattle.

To confirm the results of virological studies, molecular genetic identification of the LD-9 isolate was carried out by PCR. Real-time polymerase chain reaction results are shown in Figure 5.

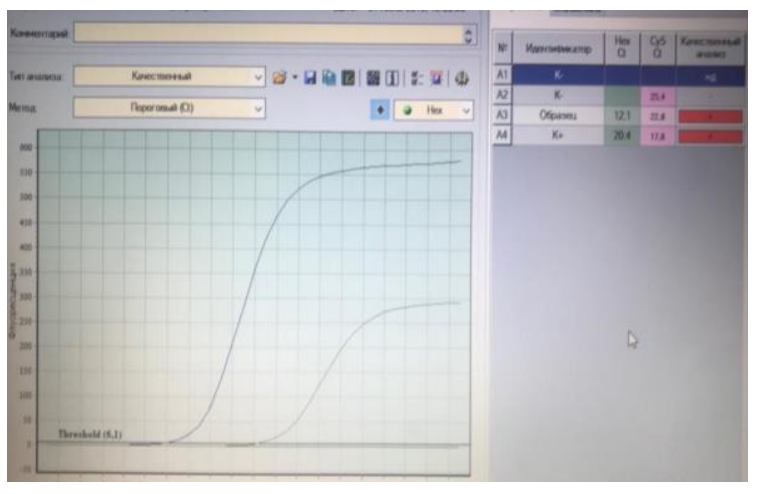

Fig. 5. Real-time PCR result.

\section{Conclusion}

The results of clinical and epizootological, pathoanatomical, séro-immunological studies, as well as the isolation of a viral agent from pathological materials with its subsequent identification with reference antisera in the PH and RDP, indicate that the main causative agent of respiratory disease in calves is the bovine parainfluenza virus type 3 . Detection of the BPIV-3 genetic material in parenchymal organs of a dead animal by PCR confirms the results of other research methods.

\section{References}

1. Y.M. Zhu, H.F. Shi, Y.R. Gao et al., Isolation and genetic characterization of bovine parainfluenza virus type 3 from cattle in China Vet. Microbiol. 149, 446-451 (2011)
2. J.K. Oem, E.Y. Lee, K.K. Lee et al., Molecular characterization of a Korean bovine parainfluenza virus type 3 isolate Vet. Microbiol. 162, 224-227 (2013)

3. R.W. Fulton, K.S. Blood, R.J. Panciera et al., Lung pathology and infectious agents in fatal feedlot pneumonias and relationship with mortality, disease onset, and treatments J. Vet. Diagn. Investig. 21, 464-477 (2009)

4. R.W. Fulton, J.D. Neill, J.T. Saliki, et al., Genomic and antigenic characterization of bovine parainfluenza-3 viruses in the United States including modified live virus vaccine $(M L V)$ strains and field strains from cattle Virus Res. 235, 77-81 (2017)

5. A.B. Hoerlein, M.E. Mansfield, F.R. Abinanti et al., Studies of shipping fever of cattle. I. Para-influenza 3 virus antibodies in feeder calves J. Am. Vet. Med. Assoc. 135, 153-160 (1959)

6. G.M. Murray, S.J. More, D. Sammin et al., Pathogens, patterns of pneumonia, and epidemiologic risk factors associated with respiratory disease in recently weaned cattle in Ireland J. Vet. Diagn. Investig. 29, 20-34 (2017)

7. J.E. Bailly, J.M. McAuliffe, M.H. Skiadopoulos et al., Sequence determination and molecular analysis of two strains of bovine parainfluenza virus type 3 that are attenuated for primates Virus Genes. 20, 173-182 (2000)

8. H.F. Shi, Y.M. Zhu, X.M. Dong et al., Pathogenesis of a genotype $c$ strain of bovine parainfluenza virus type 3 infection in albino guinea pigs Virus Res. 188, 1-7 (2014)

9. J.A. Ellis, Bovine parainfluenza-3 virus Veterinary Clinic of North America Food Animal Practice 26, 575-593 (2010)

10. H. Albayrak, Z. Yazici, E. Ozan et al., Characterisation of the First Bovine Parainfluenza Virus 3 Isolate Detected in Cattle in Turkey Vet Sci. 6(2), 167-173 (2019)

11. A.G. Glotov, T.I. Glotova, The spread of diseases of calves of viral-bacterial etiology 3, 256 (2008)

12. V.G. Gumerov, V.V. Evstifeev, Kh.N. Makaev et al., Epizootic and serological monitoring of the mixed respiratory and intestinal cattle infections KSAVM Scientific Notes 237(1), 56-60 (2019)

13. A.H. Andrews, R. Blowey, H. Boyd, R. Eddy, Respiratory disease. Bovine Medicine: Disease and Husbandry of Cattle 286-293 (2004)

14. K.J. Henrickson, Parainfluenza viruses Clin. Microbiol. Rev. 16(2), 242-264 (2003)

15. V.V. Lisitsyn, Problems of respiratory diseases of young cattle and ways of their solution Veterinary of agricultural animals 5, 12-16 (2010)

16. V.A. Mishchenko, Problem of respiratory mixed infections of young cattle in Mater. of Int. Sci. Conf. "Actual problems of infectious pathology of animals" 73-77 (2003) 
17. J.A. Ellis, The immunology of the bovine respiratory disease complex Veterinary Clinic of North America Food Animal Practice 17, 535-550 (2001)

18. P.A. Wilkens, J.C. Baker, T.R. Ames, B.P. Smith, Disease of the respiratory system Large Animal Internal Medicine 11-22 (2002)
19. K.P. Yurov, A.F. Shulyak, S.V. Alekseenkova et al., Etiology, diagnostics and prevention of massive respiratory diseases of calves in Actual problems of infectious pathology and animal immunology, Proc. of Conf. 128-132 (2006) 